\title{
IbM PENGOLAHAN KAKAO DI KABUPATEN MANOKWARI
}

\author{
S. N.P. Paiki ${ }^{1}$, M. K. Roreng ${ }^{2}$, Murtiningrum ${ }^{3}$, A. Kurniawan ${ }^{4}$
}

\begin{abstract}
ABSTRAK
Petani kakao di Kabupaten Manokwari terdiri dari petani pribumi dan petani non pribumi. Umumnya petani pribumi belum mengetahui dan memahami proses pengolahan kakao, baik untuk proses penyiapan biji kakao kering yang bermutu baik maupun produk-produk sekunder hasil olahan biji kakao. Oleh karena itu, perlu dilakukan pelatihan pengolahan biji kakao bagi petani pribumi guna meningkatkan pengetahuan dan pemahaman petani kakao tentang teknologi proses pengolahan biji kakao yang baik dan bernilai jual tinggi. Metode yang digunakan adalah penyajian materi berupa penanganan pasca panen biji kakao dan mutu biji kakao serta praktek fermentasi dan pengeringan biji kakao dan praktek pembuatan pasta, lemak, bubuk kakao, dan aplikasinya dalam pembuatan brownies sagu.
\end{abstract}

Kata kunci: IbM, kakao, lemak, bubuk kakao, Manokwari

\begin{abstract}
Cocoa farmers in Manokwari Regency consist of indigenous farmers and non-indigenous farmers. Generally indigenous farmers do not yet know and understand the cocoa processing process, both for preparing high quality of dry cocoa beans and secondary products of cocoa beans. Therefore, it is necessary to conduct cocoa bean processing training in order to increase the knowledge and understanding of cocoa farmers about the technology of good processing of cocoa beans and high commercial value. The method used was the presentation of materials about post-harvest processing and quality of cocoa beans, practice of fermentation and drying of cocoa beans, and then practice how to making pasta, fat, cocoa powder, and its application in making sago brownies.
\end{abstract}

Keywords: IbM, cacao, fat, cocoa powder, Manokwari

\section{PENDAHULUAN}

Kakao merupakan salah satu komoditas perkebunan yang peranannya cukup penting bagi perekonomian nasional, khususnya sebagai penyedia lapangan kerja, sumber pendapatan dan devisa negara. Hal ini dikarenakan industri ini memiliki keterkaitan yang luas baik kehulu maupun kehilirnya. Luas areal tanaman kakao di Provinsi Papua Barat pada tahun 2010 adalah 11.154 ha dengan jumlah produksi sebesar 5125 ton. Sementara untuk Kabupaten Manokwari memiliki luas areal tanaman kakao sebesar 3957 ha dengan jumlah produksi sebesar 2324 ton (BPS, 2011).

Petani kakao di Kabupaten Manokwari terdiri dari petani pribumi dan petani non pribumi. Berdasarkan pengamatan nampak bahwa umumnya petani non pribumi telah mengerti proses pengolahan kakao dengan baik (terutama proses penyiapan biji kakao kering yang terfermentasi). Sebaliknya untuk petani pribumi belum mengetahui dan memahami proses pengolahan kakao, baik untuk proses penyiapan biji kakao kering yang bermutu baik maupun produk-produk sekunder hasil olahan biji kakao. Umumnya penyiapan biji kakao kering oleh petani pribumi dilakukan dengan

${ }^{1234}$ Jurusan Teknologi Pertanian, Fakultas Teknologi Pertanian Universitas Papua. Email: tinnapaiki.tp@gmail.com 
tahapan pemanenan buah kakao, pembelahan, pemisahan biji dan selanjutnya langsung dikeringkan di atas aspal di pinggir-pinggir jalan raya. Penanganan yang demikian akan menghasilkan biji kakao dengan mutu lebih rendah dan sanitasi yang kurang higenis. Hal ini menyebabkan rendahnya nilai jual biji kakao di pasaran.

Berdasarkan pengamatan di lapangan terlihat bahwa nilai jual biji kakao basah dihargai sebesar Rp. $5.000,-/ \mathrm{Kg}$, sedangkan biji kakao kering sebesar Rp. 15.000,-/Kg. Dengan nilai jual yang cukup rendah tersebut menyebabkan rendahnya etos kerja petani kakao dalam memanen hasil kebunnya. Hal ini mengakibatkan petani kakao tidak mendapat keuntungan yang sepadan dengan biaya pemeliharaan kebun.

Salah satu upaya yang dapat dilakukan guna meningkatkan pendapatan petani kakao adalah dengan memberikan pengetahuan dan pemahaman kepada petani kakao tentang teknologi proses pengolahan biji kakao menjadi produk setengah jadi melalui kegiatan pelatihan. Produk setengah jadi yang dihasilkan berupa pasta, lemak, dan bubuk coklat.

\section{METODE PELAKSANAAN}

Pelaksanaan kegiatan IbM pengolahan biji kakao di Kabupaten Manokwari ini dilakukan dalam bentuk pemberian pelatihan bagi petani kakao. Metode yang digunakan dalam pelatihan ini adalah penyajian materi dan pemberian praktek kepada peserta pelatihan. Penyajian materi yang diberikan meliputi penanganan pasca panen biji kakao dan mutu biji kakao. Sedangkan praktek yang dilakukan meliputi fermentasi biji kakao dan pengolahan biji kakao dan produk olahanya.

Pelatihan ini dilaksanakan oleh tim yang terdiri dari 4 orang staf dosen pada Jurusan Teknologi Pertanian Fakultas Teknologi Pertanian UNIPA dan 2 orang mahasiswa Jurusan Teknologi pertanian. Tim terdiri Sritina N.P. Paiki, S.TP, M.Si dan Mathelda K. Roreng, S.TP, M.Si dengan bidang keahlian ilmu pangan, serta Murtiningrum, S.TP, M.Si dan Aceng Kurniawan, S.TP, M.Sc dengan bidang keahlian teknologi industri. Sedangkan mahasiswa yang terlibat adalah Demianus Kenelak (dalam proses fermentasi kakao) dan Wulan Tanlain (dalam proses pembuatan pasta, lemak, dan bubuk kakao).

\section{HASIL DAN PEMBAHASAN}

\subsection{Penyajian Materi}

Penyajian materi pada Pelatihan IbM Pengolahan Kakao di Kabupaten Manokwari dilaksanakan di Laboratorium Teknologi Pertanian. Peserta pelatihan adalah para pemilik kebun kakao di Desa Pami, Manokwari beserta keluarga dan para pekerjanya. Penyajian materi yang disampaikan meliputi penanganan pasca panen kakao oleh Sritina N. P. Paiki, S.TP, M.Si, dan mutu biji kakao oleh Mathelda K. Roreng, S.TP, M.Si. Penyajian materi dilakukan dalam bentuk ceramah dan diskusi. Ceramah dilakukan dengan bantuan LCD Proyektor dan materinya disiapkan dalam bentuk Power Point (ppt). Sementara diskusi dilakukan tujuan saling sharing informasi tentang kendala yang dihadapi oleh petani kakao dan solusinya. Penyajian materi tentang penanganan pasca panen kakao dan mutu biji kakao disajikan pada Gambar 3.1. 


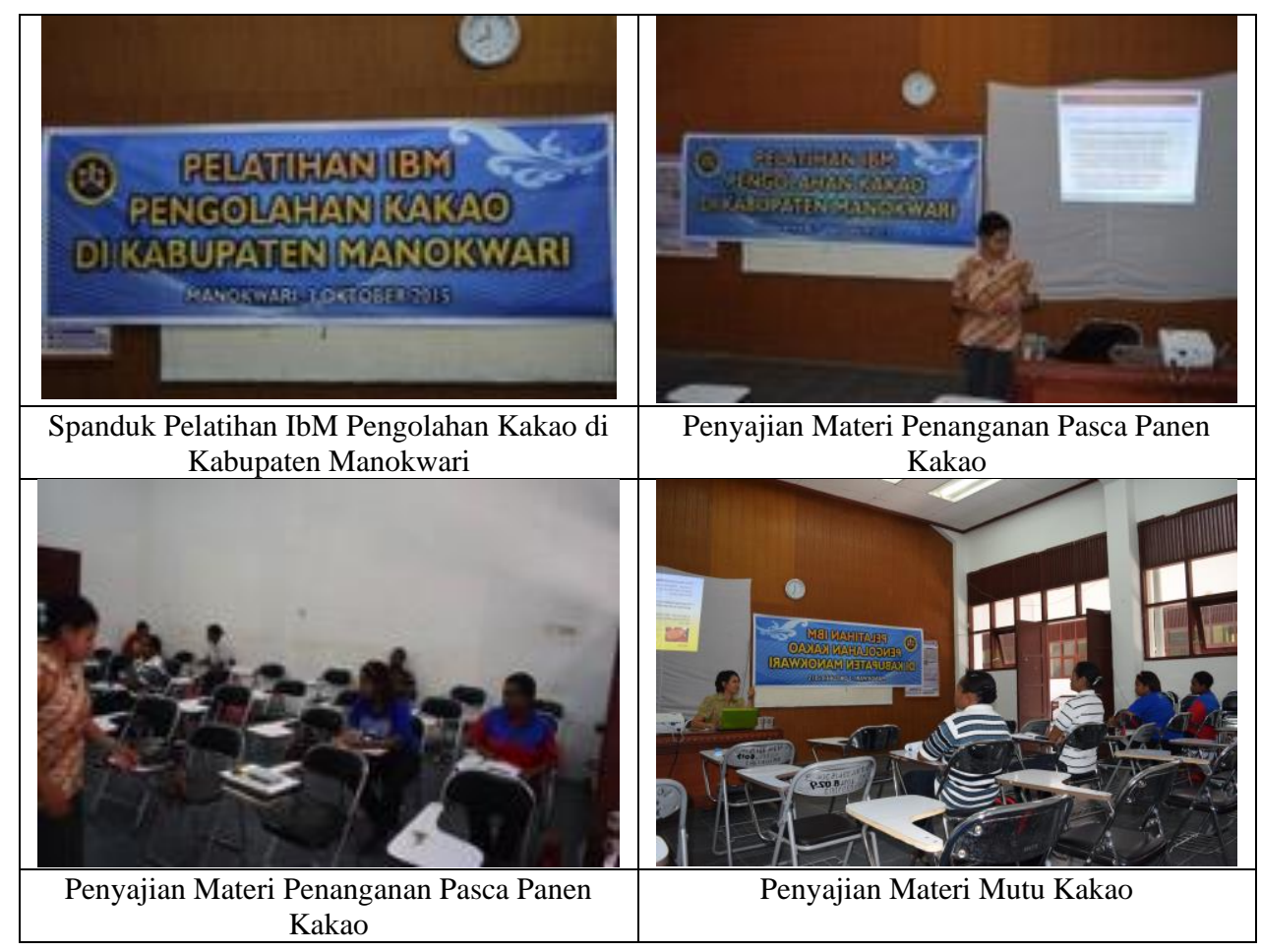

Gambar 3.1. Penyajian Materi pada Pelatihan

\subsection{Fermentasi Biji Kakao}

Kegiatan yang dilakukan pada tahap fermentasi biji kakao adalah pengumpulan biji kakao basah, yang selanjutnya akan difermentasi. Fermentasi biji kakao merupakan salah satu upaya yang dapat dilakukan guna meningkatkan mutu biji kakao. Menurut Mulanto (2010), fermentasi bertujuan untuk membentuk citarasa khas cokelat serta mengurangi rasa pahit dan sepat di dalam biji kakao. Tahapan fermentasi kakao disajikan pada Gambar 3.2.

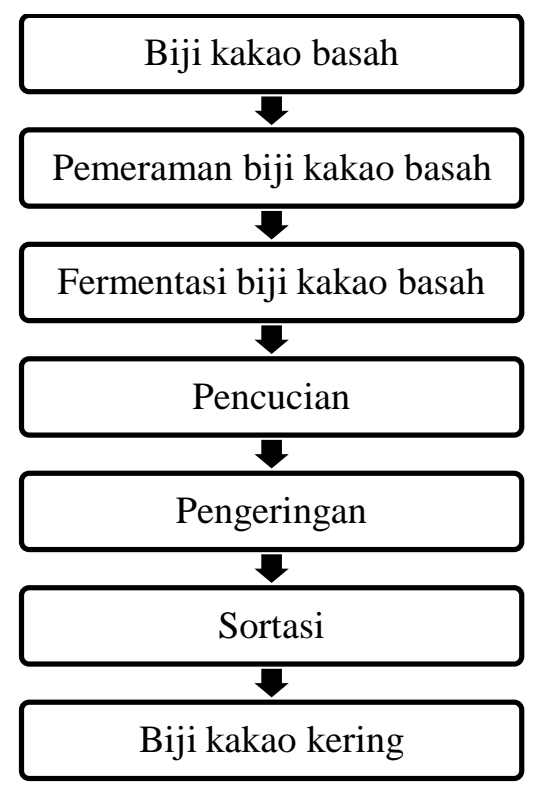

Gambar 3.2. Tahapan Fermentasi Biji Kakao 
Fermentasi dilakukan selama 4 hari (96 jam) dengan menggunakan peti fermentasi yang terbuat dari papan kayu yang diberi lubang-lubang. Proses fermentasi berlangsung secara spontan oleh mikroba alami yang ada di dalam kakao dengan bantuan oksigen dari udara. Tahap selanjutnya adalah pencucian yang bertujuan untuk menghentikan proses fermentasi, mempercepat proses pengeringan, memperbaiki kenampakan biji dan mengurangi kadar kulit. Selanjutnya dilakukan pengeringan dengan tujuan untuk menguapkan air yang masih tertinggal di dalam biji pasca fermentasi yang dilakukan dengan cara menjemur biji kakao di dalam rumah pengering. Sedangkan sortasi bertujuan untuk mengelompokan biji kakao kering berdasarkan ukuran fisiknya dan sekaligus memisahkan kotoran-kotoran yang tercampur di dalamnya. Biji kakao kering yang dihasilkan tersebut akan digunakan dalam proses pembuatan produk olahan kakao. Proses fermentasi biji kakao disajikan dalam Gambar 3.3.

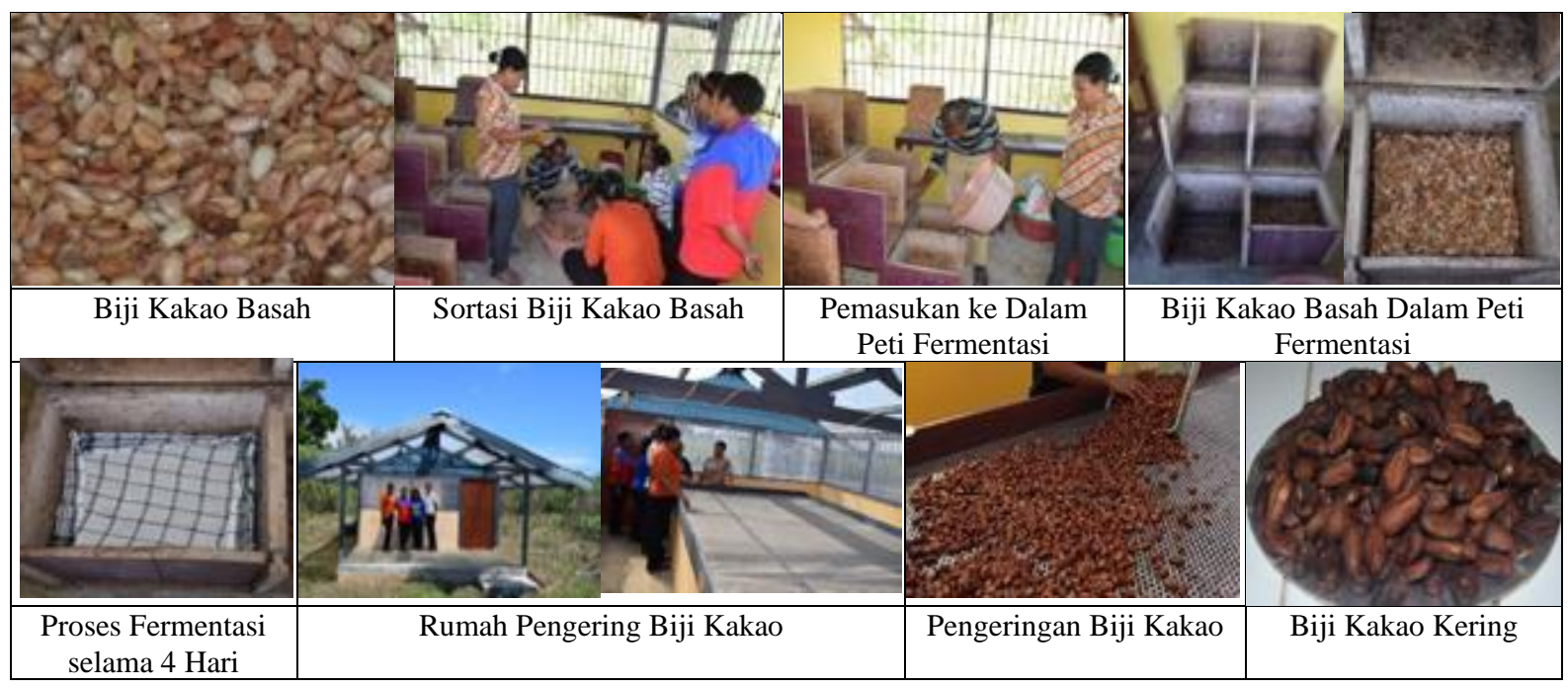

Gambar 3.3. Proses Fermentasi Biji Kakao

\subsection{Pengolahan Biji Kakao dan Produk Olahannya}

Biji kakao kering yang dihasilkan selanjutnya diolah menjadi pasta kakao, lemak kakao, dan bubuk kakao. Proses pengolahan biji kakao menjadi pasta, lemak, dan bubuk, disajikan pada Gambar 3.4. 

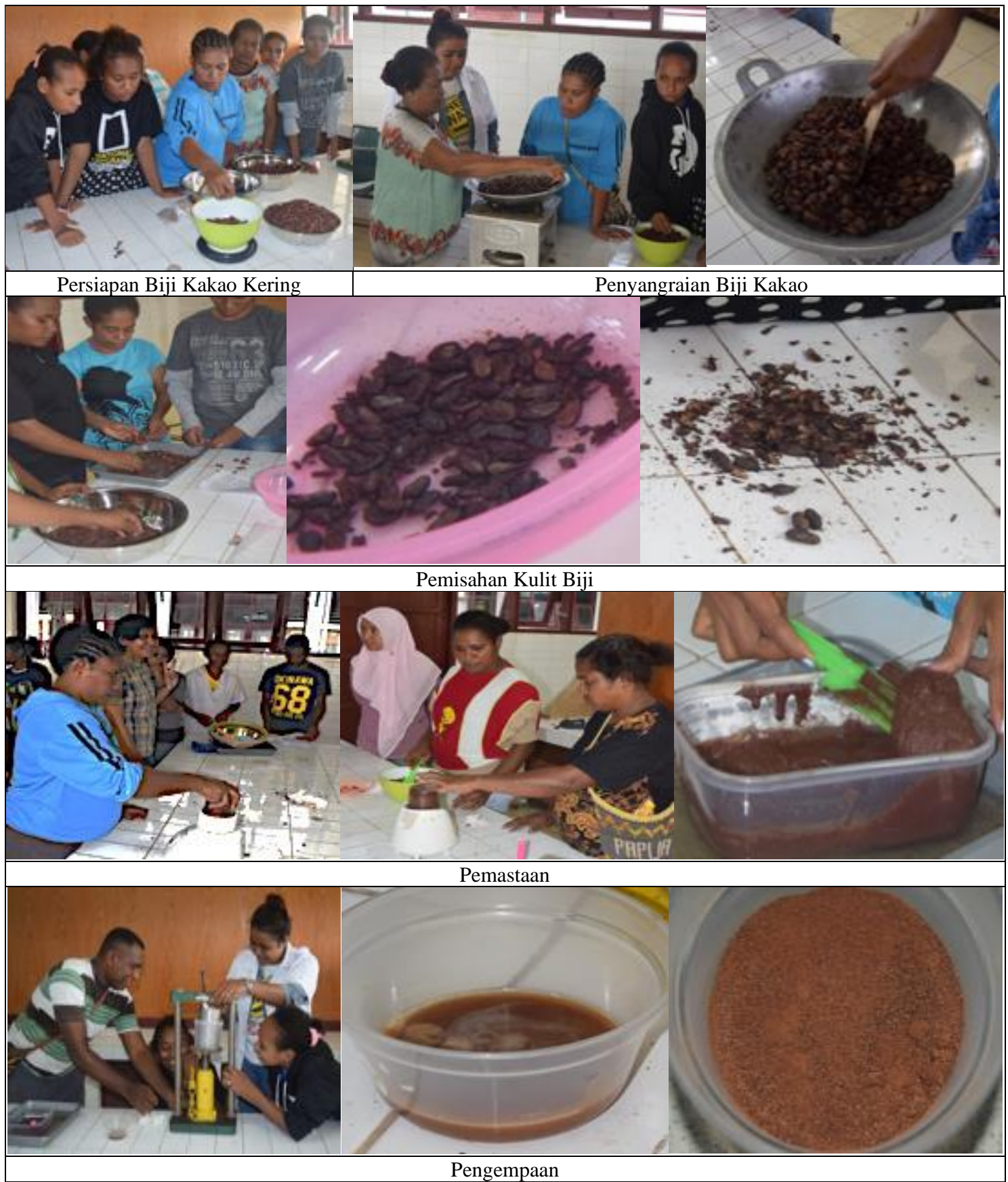

Gambar 3.4. Proses Pembuatan Pasta, Lemak, dan Bubuk kakao

Tahapan proses konversi biji kakao menjadi pasta dan lemak terdiri atas 4 tahapan yaitu penyangraian, pemisahan kulit, pemastaan, dan pengempaan. Penyangraian bertujuan untuk membentuk aroma dan citarasa khas cokelat dari biji kakao dengan perlakuan panas. Pemisahan kulit biji bertujuan untuk memisahkan kulit biji dengan daging biji (nib). Pemastaan bertujuan untuk menghancurkan daging biji kakao menjadi bentuk pasta cair kental. Sedangkan pengempaan dilakukan dengan tujuan untuk memisahkan lemak dan bungkil kakao. Pengempaan dilakukan pada suhu sekitar $40-45{ }^{\circ} \mathrm{C}$, karena lemak kakao mudah membeku pada suhu ruang. Lemak yang dihasilkan dapat langsung dijual atau dapat digunakan sebagai bahan baku atau bahan tambahan dalam pembuatan produk-produk cokelat lainnya. Sedangkan bungkil kakao yang dihasilkan kemudian dihaluskan, lalu diayak untuk memperoleh bubuk kakao dengan ukuran partikel yang 
seragam. Bubuk kakao yang dihasilkan dari bungkil merupakan bahan baku yang penting untuk makanan dan minuman cokelat. Dalam kegiatan ini bubuk cokelat yang dihasilkan digunakan sebagai bahan tambahan pada pembuatan brownies sagu. Proses pembuatan brownies sagu disajikan pada Gambar 3.5.

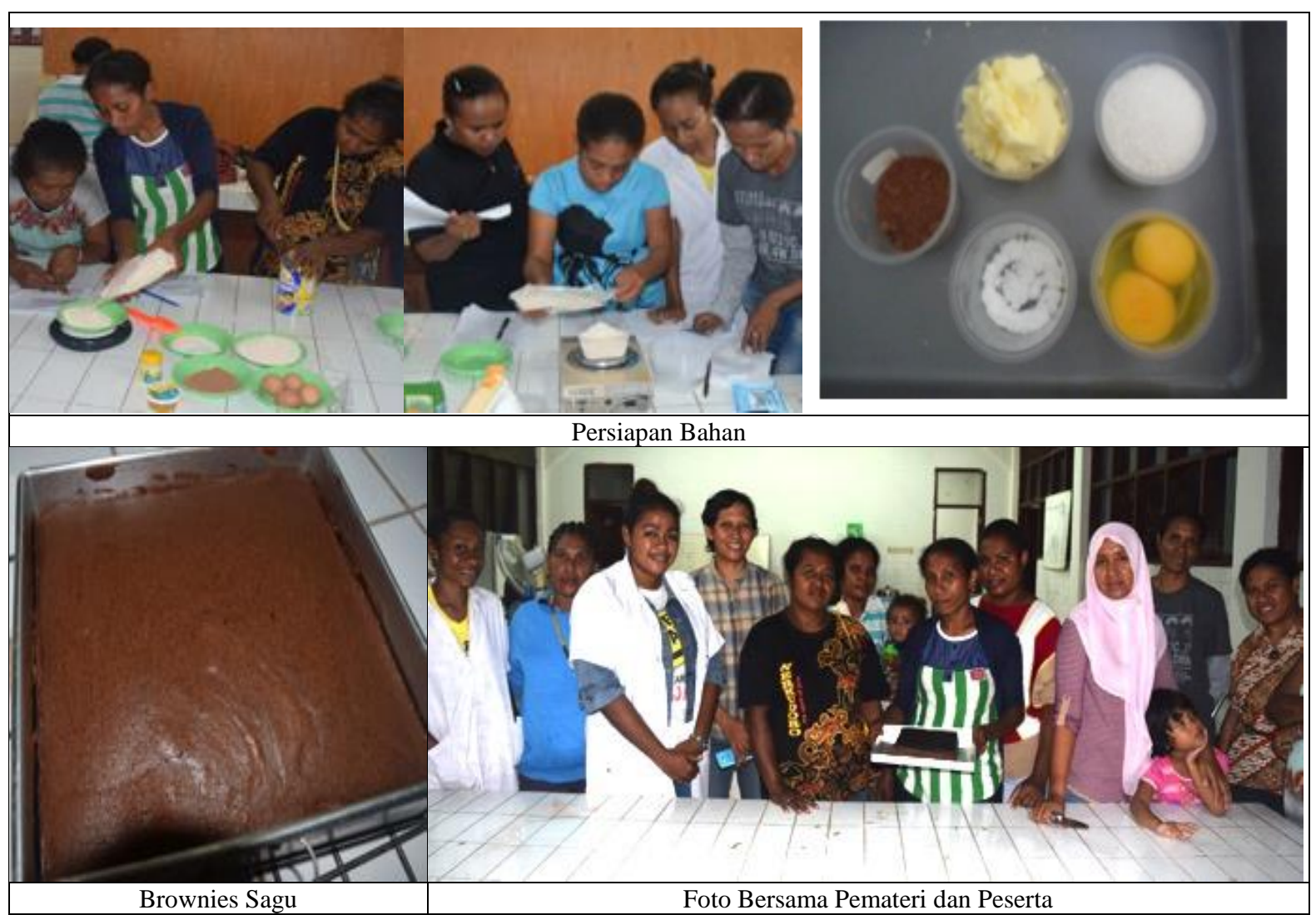

Gambar 3.5. Proses Pembuatan Brownies Sagu

\section{KESIMPULAN DAN SARAN}

\subsection{Kesimpulan}

Kegiatan yang dilakukan dalam bentuk penyajian materi berupa penanganan pasca panen biji kakao dan mutu biji kakao serta pemberian praktek berupa fermentasi biji kakao, pengolahan biji kakao fermentasi menjadi lemak dan bubuk, dan aplikasi penggunaanya dalam pembuatan brownies sagu.

\subsection{Saran}

Perlu dilakukan pelatihan lebih lanjut tentang pengemasan bubuk dan lemak kakao yang dihasilkan serta aplikasi pengolahan berbasis kakao lainnya. 


\section{UCAPAN TERIMAKASIH}

Ucapan terima kasih disampaikan kepada Direktorat Penelitian dan Pengabdian kepada masyarakat Direktorat Jendral Pendidikan Tinggi Kementerian Riset Teknologi dan Pendidikan Tinggi atas dana yang diberikan dalam bentuk Hibah Ipteks bagi Masyarakat (IbM).

\section{DAFTAR PUSTAKA}

Badan Pusat Statistik Provinsi Papua Barat. 2011. Papua Barat Dalam Angka. Badan Pusat Statistik Provinsi Papua Barat. Hal 309.

Mulanto S, Widyotomo S, Misnawi, Suharyanto E. 2010. Pengolahan Produk Primer dan Sekunder Kakao. Pusat Penelitian Kopi dan Kakao Indonesia. Jember. 